\title{
Relationship between FOXP3 positive populations and cytokine production in systemic lupus erythematosus
}

\author{
Catuxa Prado ${ }^{a}$, Banesa de Paz ${ }^{\mathrm{a}}$, Patricia López ${ }^{\mathrm{a}}$, Jesús Gómez ${ }^{\mathrm{b}}$, Javier Rodríguez-Carrio a , Ana Suárez ${ }^{\mathrm{a}, *}$ \\ a Department of Functional Biology, Immunology Area, Faculty of Medicine, C/Julián Clavería s/n, University of Oviedo, Oviedo, Asturias, Spain \\ ${ }^{\mathrm{b}}$ Department of Immunology, Hospital Universitario Central de Asturias, C/Julián Clavería s/n, Oviedo, Asturias, Spain
}

\section{A R T I C L E I N F O}

\section{Article history:}

Received 13 February 2012

Received in revised form 9 July 2012

Accepted 30 August 2012

Available online 28 September 2012

\section{Keywords}

FOXP3

SLE

Treg

IL-17A

\begin{abstract}
A B S T R A C T
In this work we studied $\mathrm{CD} 4^{+} \mathrm{FOXP3}{ }^{+}$populations in systemic lupus erythematosus (SLE) and the relationship with Th cytokine production. We found an increment in $\mathrm{CD} 25^{-} \mathrm{FOXP} 3^{+}$population in SLE associated with $\mathrm{CD} 4^{+}$downregulation and disease progression. $\mathrm{CD} 25^{\text {low }}$ cells were also upregulated and showed increased percentages of $\mathrm{FOXP3}^{+}$and $\mathrm{CD} 127^{- \text {llow }}$ cells, supporting the activated status of SLE lymphocytes. Despite the normal levels of $\mathrm{CD} 25^{\text {high }} \mathrm{FOXP}^{+}$cells, the negative correlations observed in controls with the frequency of IFN $\gamma$, TNF $\alpha$ and IL-10 secreting cells were disrupted in patients, supporting a defective Treg function. Also, CD25 $5^{\text {high }}$ cells showed an altered balance in the production of these cytokines. In addition, CD25 high $F O X P 3^{+}$cells correlated directly with IL-17A and IL-8 but not with TGF $\beta$ in SLE. The increased proportion of $\mathrm{IL}-17^{+}$cells among the $\mathrm{CD} 25^{\text {high }}$ subset and the positive correlation between IL-17 levels and Treg cells suggest a trans-differentiation of Treg into Th17 cells in SLE.
\end{abstract}

(c) 2012 Elsevier Ltd. All rights reserved.

\section{Introduction}

Systemic lupus erythematosus (SLE) is a prototypical autoimmune disorder caused by the breakdown in immune self-tolerance and characterized by a broad clinical spectrum and presence of autoantibodies against a variety of intracellular targets. Many abnormalities on both effector and regulatory $\mathrm{CD} 4^{+} \mathrm{T}$ lymphocytes have been described in SLE patients, including dysregulated intracellular signal transduction, defective apoptosis and imbalanced cytokine production, which influence B cell function and anomalous autoantibodies production.

Consistent evidence suggests that induction and maintenance of peripheral tolerance is in great part carried out by natural regulatory $\mathrm{T}$ (Treg) cells, a population of $\mathrm{CD} 4^{+}$lymphocytes which express FOXP3 and high levels of CD25 and actively suppress the activation and expansion of self-reactive $T$ cells [1]. In healthy individuals, Treg cells constitute $1-2 \%$ of the $\mathrm{CD} 4^{+}$lymphocytes in peripheral blood and display potent suppressive activity, inhibiting the production of TNF $\alpha$ and IFN $\gamma$, among others. Many groups have

Abbreviations: SLE, systemic lupus erythematosus; FOXP3, forkhead box protein 3; Treg, regulatory $\mathrm{T}$ cells; $\mathrm{Th}, \mathrm{CD}^{+} \mathrm{T}$ helper cells.

* Corresponding author. Address: Dpto. Biología Funcional (Área de Inmunología), Facultad de Medicina, $4^{\mathrm{a}}$ planta, C/Julián Clavería s/n, Oviedo, Asturias, Spain. Tel.: +34 985102789; fax: +34985103534.

E-mail addresses: pradocatuxa@uniovi.es (C. Prado), banessina@hotmail.com (B. de Paz), lopezpatricia@uniovi.es (P. López),jegomez2000uk@yahoo.com (J. Gómez) javiercarrio@hotmail.com (J. Rodríguez-Carrio), anasua@uniovi.es (A. Suárez). evaluated the role of the Treg population in the pathogenesis of autoimmune diseases, reporting most of them reduced levels or impaired function in several pathologies. In SLE, contradictory results have been published and it remains controversial as to whether or not the frequency or the function of Treg cells are altered [2]. These heterogeneous results could be partly explained by the use of different methodologies to quantify and isolate Treg cells or to determine their suppressive capability. Although FOXP3 has been widely used to identify thymus derived $\mathrm{CD} 4^{+} \mathrm{CD} 25^{\text {high }}$ naturally occurring Treg cells [3], it is well known that this transcription factor is also expressed in peripheral induced Treg [4] and even in human activated $\mathrm{T}$ cells without suppressive activity [5]. Besides CD25 and FOXP3, other surface markers, like CD127-llow, $\mathrm{CD}_{45 \mathrm{RO}}+, \mathrm{CTLA}-4^{+}$and $\mathrm{GITR}^{+}$, have been commonly used to identify Treg population but, unfortunately, this phenotype is also shared by activated or memory Th cells. Besides, more recently researchers have paid attention to a little known subpopulation of $\mathrm{FOXP}^{+} \mathrm{CD}^{+}$cells lacking $\mathrm{CD} 25$ expression, since it has been found to be augmented in peripheral blood from lupus patients [6-9]. Nevertheless, the function and the clinical significance of $\mathrm{CD} 4^{+} \mathrm{CD} 25^{-}$cells, as well as the reason why this subpopulation is increased in SLE, remain unknown.

It has been proposed that conventional $\mathrm{CD}^{+} \mathrm{FOXP}^{+}$Treg cells control immune responses to self and foreign antigens mainly by inhibiting the proliferation and/or the function of effector $\mathrm{T}$ cells, thus blocking the production of proinflammatory cytokines and maintaining an adequate balance between effector and regulatory 
$\mathrm{CD}^{+} \mathrm{T}$ cell subsets. In spite of this, a substantial Treg plasticity has been described in the last years. Specifically, Treg cells have shown to be capable of assuming Th17 effector functions under certain conditions, such as the presence of a proinflammatory environment [10-12]. The development of both Treg and Th17 cells is critically dependent on the cytokine milieu, with IL-1 $\beta$ and IL-6 driving $\mathrm{CD}^{+} \mathrm{T}$ cells to secrete IL-17A [13], a cytokine that acts on a broad range of cell types to induce the production of inflammatory mediators, including IL-8 [14] and GM-CSF [15]. On the contrary, TGF $\beta 1$ plays a fundamental role in the induction and maintenance of Treg cells and seems to be involved in the antiproliferative function [16].

In this work we investigated the different $\mathrm{FOXP}^{+}{ }^{+}$populations present in SLE patients and healthy controls and, aimed to evaluate their putative suppressive function, the possible relationship with Th effector populations and cytokine serum levels.

\section{Materials and methods}

\subsection{Patients and controls}

The study included 75 SLE patients selected from the Asturian Register of Lupus $[17,18]$, eight of them with a disease duration of less than 1 year. All patients fulfilled at least four of the American College of Rheumatology criteria for SLE. Information on clinical and immunological manifestations was obtained by reviewing clinical histories. Disease activity was scored at the time of sampling based on the SLE disease activity index (SLEDAI) and antidsDNA titer. Patients with SLEDAI score $\geqslant 8(n=16)$ were considered to have moderate/high disease activity. Patients were also asked questions about the treatment they received over the previous three months. Twenty-nine sex and age-matched healthy blood donors were used as controls ( 25 women and 4 men; mean age \pm SD: $44.6 \pm 12.2$ ). All participants provided written informed consent according to the Declaration of Helsinki. The study was approved by the regional Ethics Committee for Clinical Investigation.

\subsection{Phenotypic analysis of $C D 4^{+} T$ cells}

Expression of Treg markers on $\mathrm{CD}^{+} \mathrm{T}$ cells from patients and controls were determined by multiparametric flow cytometry. Whole blood cells were extracellularly stained with CD4 APCCy7, CD25 FITC, CD45RO APC (purchased from BD Pharmingen, California, USA) and anti-CD127 PE-Cy7 (eBiosciences) or with the corresponding isotype-matched and fluorochrome-matched controls (BD Pharmingen). To assess FOXP3 expression, cells were fixed, permeabilized and intracellularly stained with anti-FOXP3 PE (clone PCH101) or isotype control following the manufacturer's instructions for whole blood (Human FOXP3 staining kit, eBiosciences). The lymphocyte population was gated according to forward and side-scattered properties and $\mathrm{CD}^{+} \mathrm{T}$ cells were gated using anti-CD4 antibodies. Isotype controls were used to set up the negative population and, according to the intensity of CD25 expression, $\mathrm{CD} 4^{+} \mathrm{CD} 25^{+}$T cells were subdivided into $\mathrm{CD} 25^{\text {low }}$ and CD25 $5^{\text {high }}$ populations. These two cellular subsets were further characterized by multiparametric phenotypic analysis after acquiring $10000 \mathrm{CD}^{+}$lymphocytes. Analyses were carried out on a BD FACSCanto II flow cytometer (BD Pharmingen) with FACSDiva Software 6.1.2 (BD Pharmingen).

\subsection{Production of intracellular cytokines}

Intracellular accumulation of cytokines was evaluated at the single cell level by flow cytometry after stimulation of isolated cells in the presence of a Golgi inhibitor. To this end, PBMC were separated from heparinised blood samples by Ficoll-Hypaque density gradient centrifugation and resuspended at a concentration of $2 \times 10^{6}$ cells/ml in RPMI 1640 medium (Invitrogen, UK) supplemented with $10 \%$ of heat inactivated FCS (Hyclone, USA), penicillin $(20 \mathrm{U} / \mathrm{ml})$ and streptomycin $(20 \mu \mathrm{g} / \mathrm{ml})$. Isolated cells were stimulated with $20 \mathrm{ng} / \mathrm{ml}$ of PMA and $500 \mathrm{ng} / \mathrm{ml}$ of ionomycin in the presence of $2 \mu \mathrm{M}$ of monensin (all of them from Sigma Aldrich, Germany) for $5 \mathrm{~h}$ at $37^{\circ} \mathrm{C}$ in $5 \% \mathrm{CO}_{2}$. After that, cells were washed twice with PBS + 3\% FCS and stained for surface markers with antiCD4 APC and anti-CD25 PE-Cy7 (BD Pharmingen). Then cells were fixed, permeabilized and intracellularly stained with anti-IL-10 PE (BD Pharmingen) and anti-TNF $\alpha$ PerCP-Cy5.5 (eBioscience) or with anti-IL-17A PE and anti- IFN $\gamma$ PerCP-Cy5.5 (from eBioscience). Fixation and permeabilization were carried out using the Cytofix/ Cytoperm Fixation/Permeabilization Kit (BD Pharmingen) following the manufacturer's recommendations. The corresponding isotype and fluorochrome-matched controls were used to set up quadrants. A minimum of $10000 \mathrm{CD}^{+} \mathrm{T}$ lymphocytes were acquired and analyzed (BD FACSCanto II). Results are expressed as the percentage of positive cells or as the MFI of the gated population.

\subsection{Cytokine quantification in serum samples}

The amounts of IFN $\alpha$, IL-1 $\beta$, IL- 6 , IL- 8 and IL-17A were quantified by flow cytometry using BD ${ }^{\mathrm{TM}}$ Cytometric Bead Array (CBA) Flex Sets or BD ${ }^{\text {TM }}$ CBA Enhanced Sensitivity Flex Sets. The detection limits were: IFNa: $1.5 \mathrm{pg} / \mathrm{ml}$; IL-8: $1.2 \mathrm{pg} / \mathrm{ml}$; IL-1 $\beta$ : $48.4 \mathrm{fg} / \mathrm{ml}$; IL6: $68.4 \mathrm{fg} / \mathrm{ml}$; IL-17A: $26.1 \mathrm{fg} / \mathrm{ml}$. The concentration of TGF $\beta 1$ was measured by ELISA (Human TGF $\beta 1$ ELISA Set, BD OptEIA ${ }^{\mathrm{TM}}$ ). The detection limit was $11.9 \mathrm{ng} / \mathrm{ml}$.

\subsection{Statistical analysis}

Values are shown as median and interquartile range (IR) throughout the manuscript unless otherwise stated. Mann-Whitney $U$ test was used to evaluate differences between groups. Correlations between variables were carried out using Spearman's rank correlation test. All statistical analyses were performed using the SPSS software (version 15.0). Graphs were drawn with GraphPad Prism software (version 4.0).

\section{Results}

\subsection{Increased number of $\mathrm{CD}_{2} 5^{-} \mathrm{FOXP3^{+ }}$ cells in SLE patients}

We determined the frequency and phenotype of $\mathrm{FOXP}^{+}$cells with different $\mathrm{CD} 25$ expression in $\mathrm{CD}^{+}$lymphocytes from 29 healthy controls and 75 SLE patients, 8 of them diagnosed during the last year (Fig. 1A). Demographic and clinical details of patients are given in Table 1. SLEDAI score, anti-dsDNA titer and IFN $\alpha$ levels were determined as indicators of disease activity. Table 2 shows that the amount of total $\mathrm{FOXP}^{+}$and $\mathrm{FOXP3}^{+} \mathrm{CD} 127^{-/ \text {low }}$ cells was significantly higher in SLE patients compared to healthy controls (HCs). However, levels of CD25 ${ }^{\text {high }}$ FOXP3 ${ }^{+}$and $C D 25^{\text {high }} \mathrm{CD} 127^{-1}$ low cells, the so-called natural Treg, were similar in patients and controls, whereas the proportion of $\mathrm{CD} 25^{-}$and $\mathrm{CD} 25^{\text {low }}$ cells expressing $\mathrm{FOXP}^{+}{ }^{+}$was strikingly increased in patients. Of note, CD25 $5^{\text {low }}$ cells were significantly augmented in SLE patients, while $\mathrm{CD}^{-}$cells were reduced. Furthermore, the amount of $\mathrm{CD} 127^{-1}$ low cells expressing low CD25 levels was also higher in patients compared with controls, thus suggesting an activated condition of SLE lymphocytes.

No significant differences were detected in any $\mathrm{FOXP}^{+} \mathrm{CD} 4^{+} \mathrm{T}$ cell subset related to treatment or disease activity, however, 
A
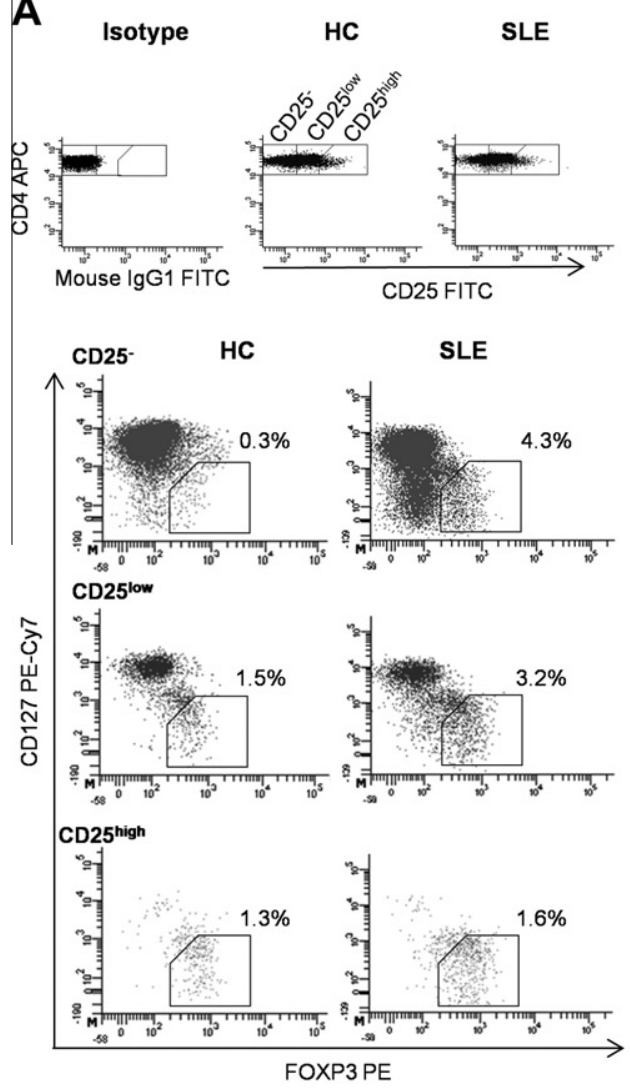

B
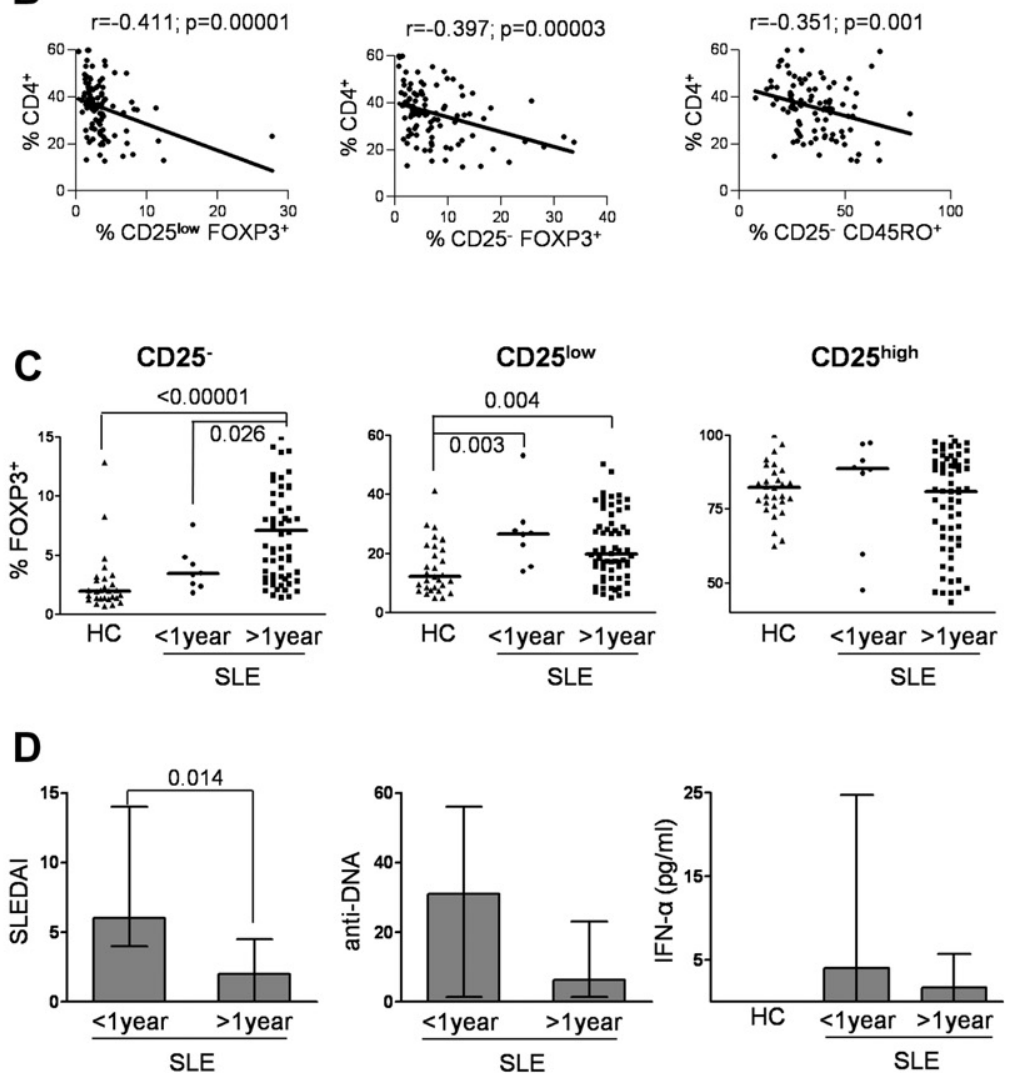

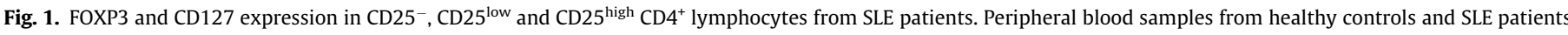

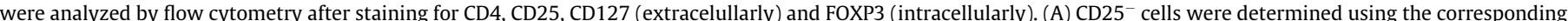

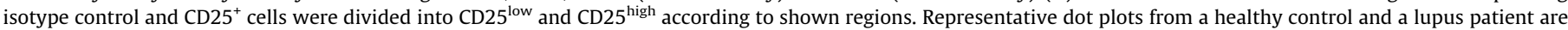

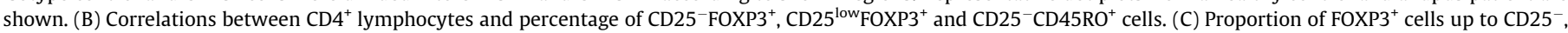

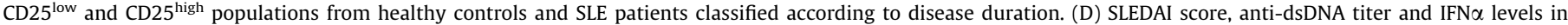

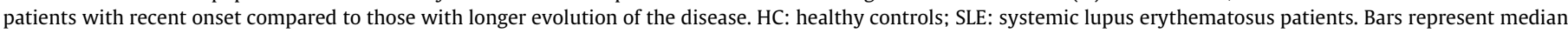
(IR).

$\mathrm{CD}^{-} 5^{-}$and $\mathrm{CD} 25^{\text {low }} \mathrm{FOXP}^{+}$cells were inversely correlated with the amount of $\mathrm{CD}^{+}$lymphocytes (Fig. 1B). Moreover, we also found that $\mathrm{CD} 4^{+} \mathrm{T}$ cells dropped in parallel with an increment in the size of $\mathrm{CD}_{25} 5^{-} \mathrm{CD} 45 \mathrm{RO}^{+}$population (Fig. 1B), thus suggesting a selective reduction of $\mathrm{FOXP}^{-} \mathrm{CD}^{-} 5 \mathrm{RO}^{-} \mathrm{CD} 25^{-/ \text {low }} \mathrm{CD}^{+}$lymphocytes in SLE patients.

As expected, $\mathrm{CD}^{+} \mathrm{T}$ cells were downregulated in our SLE patient group ( $40.74 \pm 9.46 \%$ vs $33.45 \pm 10.97 \%$; $p=0.002$ ), but a striking reduction was only found in patients with established disease $(32.97 \pm 11.26 \%)$, whereas no significant decline was observed in patients with relatively recent onset (less than 1 year) ( $37.44 \pm 7.64 \%)$. Thus, since $\mathrm{CD} 25^{-}$population was significantly reduced in our patient group (Table 2 ), we analyzed the percentage of $\mathrm{FOXP}^{+}$cells out of $\mathrm{CD} 25^{-}, \mathrm{CD} 25^{\text {low }}$ and $\mathrm{CD} 25^{\text {high }}$ subsets in SLE patients classified according to disease duration. Fig. 1C shows that patients with disease duration longer than 1 year presented significantly raised frequency of $\mathrm{FOXP}^{+}$cells in the $\mathrm{CD} 25^{-} \mathrm{CD} 4^{+}$ subset. However, among CD25 $5^{\text {low }}$ cells, the highest amount of $\mathrm{FOXP3}^{+}$cells was displayed by SLE patients diagnosed in the last year, a patient group that also presented the highest SLEDAI score, anti-dsDNA titer and IFN $\alpha$ levels (Fig. 1D), thus suggesting once again that $\mathrm{CD}^{2} 5^{\text {low }}$ FOXP3 $^{+}$cells may include activated lymphocytes in patients with active disease.

Differences in $\mathrm{CD}_{25}{ }^{-} \mathrm{FOXP3}^{+}$population between recent onset patients and those with longer disease duration did not seem to be related to treatment or disease activity. In fact, just two patients with recent onset were users of high corticoid dose $(20 \mathrm{mg} /$ day $)$ and displayed active disease (SLEDAI score: 22 and 6; anti-dsDNA titer: 400 and $56 \mathrm{U} / \mathrm{ml}$ ), but they presented low amount of FOXP3 ${ }^{+}$ cells in the CD25- subset (3.35\% and 4.22\%). The others recent onset patients were untreated $(n=5)$ or under antimalarial treatment $(n=1)$. All these results suggest that the upregulation of Treg markers on the $\mathrm{CD} 25^{-}$population does not associate with disease activity or treatment followed.

\subsection{Association between $\mathrm{CD} 25^{\text {high }} \mathrm{FOXP}^{+}$cells and cytokine producing cells}

Given the impossibility to isolate the distinct $\mathrm{FOXP3}^{+}$subpopulations, in an attempt to evaluate the in vivo functional ability of these cells, we analyzed their possible relationship with the amount of memory CD4 ${ }^{+}$effector cells determined ex vivo in SLE and $\mathrm{HC}$, since inhibition o Th-derived cytokines is a function of regulatory $\mathrm{T}$ cells. To this end, we analyzed by flow cytometry the intracellular accumulation of IL-10, TNF $\alpha$, IL-17 and IFN $\gamma$ in $\mathrm{CD}^{2} \mathrm{RO}^{+} \mathrm{CD}^{+} \mathrm{T}$ cells after $5 \mathrm{~h}$ of stimulation with ionomycin and PMA (Fig. 2A), in parallel with the analysis of FOXP3 and CD25 expression. Fig. 2B shows that in $\mathrm{HC}$ the percentages of $\mathrm{CD}^{+} \mathrm{CD}^{+} 5 \mathrm{RO}^{+}$lymphocytes producing either IFN $\gamma$, TNF $\alpha$ or IL10 , were negatively correlated with the frequency of $\mathrm{CD} 25^{\text {high- }}$ $\mathrm{FOXP3}^{+}$cells, supporting that this conventional Treg population plays a role in controlling effector Th functions and cytokine production. We did not find, however, any significant correlation in SLE patients, suggesting that the in vivo function of these cells 
Table 1

Characteristics and disease parameters from SLE patients.

\begin{tabular}{ll} 
Total SLE patients, n & 75 \\
Women/men & $72 / 3$ \\
Age at diagnosis (mean \pm SD), years & $35.36 \pm 14.30$ \\
Disease duration (mean \pm SD), years & $12.40 \pm 8.91$ \\
Clinical manifestations, n (\%) & \\
Malar rash & $40(53.3)$ \\
Discoid lesions & $10(13.3)$ \\
Photosensitivity & $45(60.0)$ \\
Oral ulcers & $34(45.3)$ \\
Arthritis & $56(74.7)$ \\
Serositis & $13(17.3)$ \\
Renal disorder & $26(34.7)$ \\
Neurological disorder & $7(9.3)$ \\
Haematological disorder & $51(68.0)$ \\
Presence of anti-dsDNA & $55(73.3)$ \\
Anti-dsDNA titer (mean \pm SD), U/ml & $28.9 \pm 58.9$ \\
Presence of anti-ENA & $36(48.0)$ \\
Presence of anti-SSA & $29(38.6)$ \\
Presence of anti-SSB & $14(18.6)$ \\
Presence of anti-Sm & $9(12)$ \\
Presence of anti-RNP & $13(17.3)$ \\
Treatment, n (\%) & \\
None or NSAIDs & $12(16.0)$ \\
AM alone & $29(38.7)$ \\
GC alone & $7(9.3)$ \\
AM + GC & $12(16.0)$ \\
Immunosuppressive drugs ${ }^{\mathrm{a}}$ & $15(20.0)$ \\
\hline A A & \\
\hline
\end{tabular}

a Azathioprine, cyclosporine A, mycophenolate mophetil or ciclophosphamide SLE, systemic lupus erythematosus; SD, standard deviation; NSAIDs, non steroidal anti-inflammatory drugs; AM, antimalarial drugs; GC, glucocorticoids.

Table 2

Size of $\mathrm{CD}^{+} \mathrm{T}$ cell subsets in healthy controls and SLE patients.

\begin{tabular}{|c|c|c|c|}
\hline$\%$ out of $\mathrm{CD}^{+} \mathrm{T}$ cells & $\mathrm{HC}$ & SLE patients & $p$ value \\
\hline $\mathrm{FOXP}^{+}$ & $6.41(4.23)$ & $10.22(6.89)$ & 0.001 \\
\hline $\mathrm{FOXP}^{+} \mathrm{CD} 127^{-/ \text {low }}$ & $5.67(3.23)$ & $8.59(6.77)$ & 0.001 \\
\hline CD25 high & $2.60(2.99)$ & $2.95(3.07)$ & 0.191 \\
\hline $\mathrm{CD} 5^{\text {high }} \mathrm{FOXP3}^{+}$ & $1.47(0.92)$ & $1.65(1.91)$ & 0.333 \\
\hline $\mathrm{CD} 25^{\text {high }} \mathrm{CD} 127^{-/ \text {low }}$ & $1.94(1.35)$ & $2.10(2.43)$ & 0.303 \\
\hline $\mathrm{CD}^{2} 5^{\text {high }} \mathrm{CD} 45 \mathrm{RO}^{+}$ & $1.62(1.44)$ & $0.90(0.89)$ & 0.039 \\
\hline $\mathrm{CD} 25^{\text {low }}$ & $13.69(11.64)$ & $19.06(9.10)$ & 0.002 \\
\hline 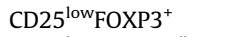 & $2.19(1.69)$ & $3.42(1.86)$ & 0.0003 \\
\hline $\mathrm{CD} 25^{\text {low }} \mathrm{CD} 127^{- \text {llow }}$ & $5.18(2.11)$ & $6.14(3.52)$ & 0.019 \\
\hline $\mathrm{CD}^{2} 5^{\text {low }} \mathrm{CD} 45 \mathrm{RO}^{+}$ & $9.62(7.61)$ & $8.10(6.77)$ & 0.239 \\
\hline $\mathrm{CD}_{25}^{-}$ & $83.39(14.61)$ & $77.72(10.56)$ & 0.003 \\
\hline $\mathrm{CD}^{2} 5^{-} \mathrm{FOXP}^{+}$ & $3.13(2.18)$ & $6.71(7.25)$ & 0.00001 \\
\hline $\mathrm{CD} 25^{-} \mathrm{CD} 127^{-/ \mathrm{low}}$ & $23.86(13.55)$ & $25.62(21.00)$ & 0.876 \\
\hline $\mathrm{CD}_{25}{ }^{-} \mathrm{CD} 45 \mathrm{RO}^{+}$ & $28.85(15.37)$ & $35.90(18.10)$ & 0.121 \\
\hline
\end{tabular}

Data are shown as median (IR). Differences between patients and controls were evaluated using the Mann-Whitney $U$ test. $p$ values in bold are considered statistically significant $(\mathrm{p}<0.05)$ HC: healthy controls; SLE systemic lupus erythematosus.

may be impaired in lupus. On the other hand, neither HC nor SLE patients displayed significant correlations between the percentages of $\mathrm{CD}_{25}^{-}$or $\mathrm{CD} 25^{\text {low }} \mathrm{FOXP}^{+}$cells and the number of cytokine producing cells. Thus, these $\mathrm{FOXP3}^{+}$populations do not seem to be involved in regulating the production of these cytokines.

Interestingly, we noticed that neither $\mathrm{CD}_{2} 5^{\text {high }} \mathrm{FOXP3}^{+}$cells from HC nor SLE patients correlated with the percentage of IL$17^{+}$cells (Fig. 2B). In addition, we found that the frequency of $\mathrm{CD} 25^{\text {high }}$ cells that produce IL-17 in lupus was slightly increased in patients with moderate/high disease activity (HC: 0.95 (1.12); SLEDAI $\leqslant 8: 1.02(1.16) ;$ SLEDAI > 8: 1.65 (1.05)). These data seem to suggest that $\mathrm{CD} 25^{\text {high }}$ cells from active lupus patients are more prone to secrete IL-17 rather than suppress its production. In fact, IL- $17^{+} / \mathrm{FOXP}^{+}$ratio within $\mathrm{CD} 25^{\text {high }}$ cells was significantly higher in these SLE patients compared with HC (Fig. 2C), indicating the existence of an important shift in the function of $C D 25^{\text {high }}$ from SLE patients. Similarly, we found that $\mathrm{IL}-17^{+} / \mathrm{IFN} \gamma^{+}$and $\mathrm{IL}-17^{+} /$ $\mathrm{TNF}^{+}$balances in $\mathrm{CD} 25^{\text {high }}$ cells from patients with moderate/high disease activity were significantly increased (Fig. 2C), confirming that CD25 $5^{\text {high }}$ cells from SLE are different from those from healthy individuals. On the contrary, no differences were detected among CD25-/low cells.

\subsection{Cytokine serum levels and their relationship with $\mathrm{CD} 4^{+} \mathrm{FOXP} 3^{+}$ cells}

Since both $\mathrm{FOXP3}^{+}$and Th17 cells seem to be involved in the pathogenesis of SLE, we wanted to investigate the possible relationship between several cytokines, related to the generation or the effector functions of Th17 and Treg cells, and the alterations found in $\mathrm{FOXP}^{+}$cells from lupus patients. To this end, we measured IL-1 $\beta$, IL-6, IL-8, IL-17, TGF $\beta 1$ and GM-CSF in the serum of SLE patients and HC. We found increased levels of IL- 6 in patients compared with HC (mean \pm SD: $0.68 \pm 0.86$ vs $2.74 \pm 4.30 \mathrm{pg} / \mathrm{ml}$, $p=0.0002$ ). Also, IL-8 and GM-CSF were upregulated in SLE (IL-8: $13.3 \pm 8.0$ vs $42.0 \pm 78.6 \mathrm{pg} / \mathrm{ml}, p=0.0001$; GM-CSF: $2.31 \pm 3.23$ vs $4.3 \pm 6.05 \mathrm{pg} / \mathrm{ml}, p=0.014$ ) whereas the concentration of TGF $\beta$ was found to be decreased in our patient group (19.1 \pm 4.2 vs $13.8 \pm 4.1 \mathrm{ng} / \mathrm{ml}, p \leqslant 0.001)$. No significant differences were detected in the levels of IL-1 $\beta(101.2 \pm 169.2$ vs $257.5 \pm 582.2 \mathrm{fg} / \mathrm{ml})$ and IL-17 $(5.2 \pm 20.8$ vs $7.8 \pm 13.0 \mathrm{pg} / \mathrm{ml})$. Of note, a correlation was detected between IL-17 serum levels and the amount of effec-

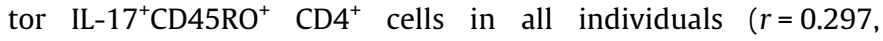
$p=0.009$ ), although it was only significant in SLE patients $(r=0.278, p=0.034)$.

As expected, TGF $\beta$ serum levels correlated positively with the frequency of $\mathrm{CD} 25^{\text {high }} \mathrm{FOXP} 3^{+}$cells in $\mathrm{HC}$, but this association was not present in SLE patients (Fig. 3A). Instead, the number of CD25 ${ }^{\text {high }} \mathrm{FOXP}^{+}$cells in SLE was positively correlated with serum levels of IL-17 and IL-8 and negatively with IL-6 (Fig. 3B). This association between Treg cells and IL-17 levels in patients supports the previous suggestion that CD25 $5^{\text {high }}$ cells in SLE could secrete IL-17. On the other hand, the percentage of $\mathrm{CD} 25^{-}$or $\mathrm{CD} 25^{\text {low }} \mathrm{FOXP}^{+}$ cells was not associated with the amount of any tested cytokine, confirming the observations made in the experiments to test the ex vivo production of cytokines.

\section{Discussion}

This work describes significant alterations in the FOXP3 ${ }^{+}$population of SLE patients which could be relevant in the pathogenesis of the disease. First, we showed that $\mathrm{CD} 25^{-} \mathrm{FOXP}^{+}$cells were considerably increased in patients compared with controls, supporting the idea that FOXP3 expression is dissociated from that of CD25. These results are in line with recent reports [6-9] and suggest that presence of increased $\mathrm{FOXP3}^{+}$cells lacking CD25 expression could be a typical feature of SLE. Nevertheless, the source of this population and the reason why it is increased in lupus remains unknown. These cells are habitually present in all individuals, actually, a half of the total circulating $\mathrm{CD} 4^{+} \mathrm{FOXP} 3^{+}$cells in our healthy group belong to the CD25- subset, but this figure rises to 70\% in SLE patients. This enhancement could be secondary to changes in inflammatory status or specific clinical features, although, in contrast with other reports $[6,9,19]$, we did not find any association with disease activity. However, our data suggest that the increase in this population could be influenced by the progression of the immune disorder, since the proportion of $\mathrm{FOXP3}^{+}$cells among the $\mathrm{CD} 25^{-}$ subset is higher in patients with a disease duration longer than one year compared to those with recent onset or with healthy controls. In view of this data, we can hypothesize that the expression 
A
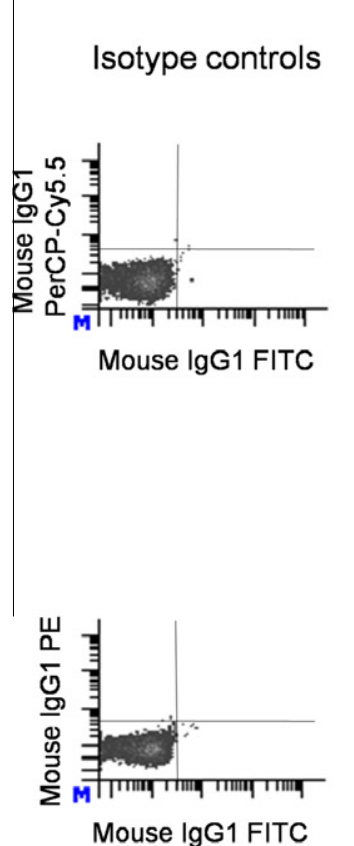
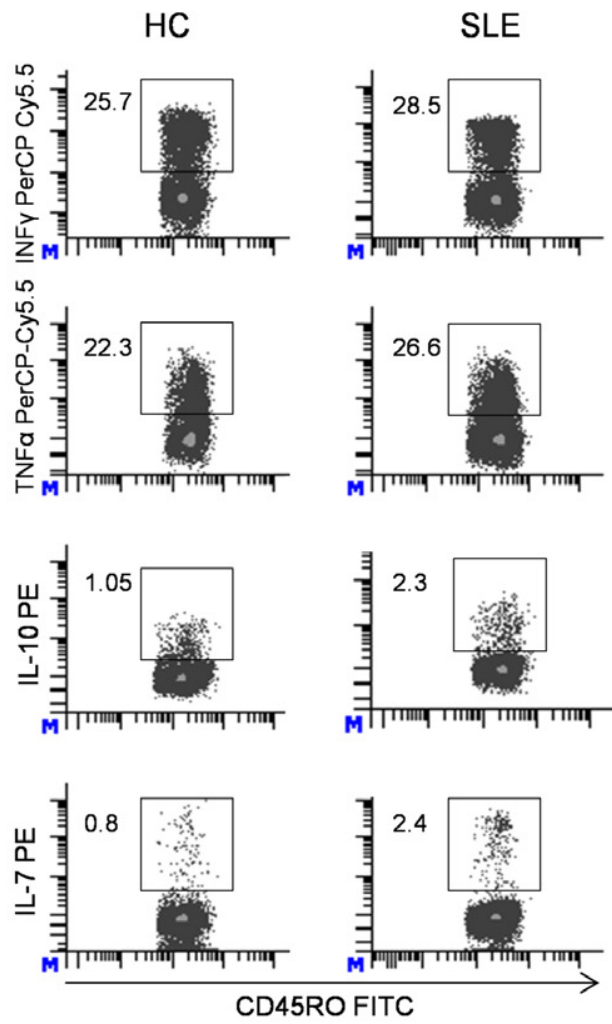

$\mathrm{HC}$
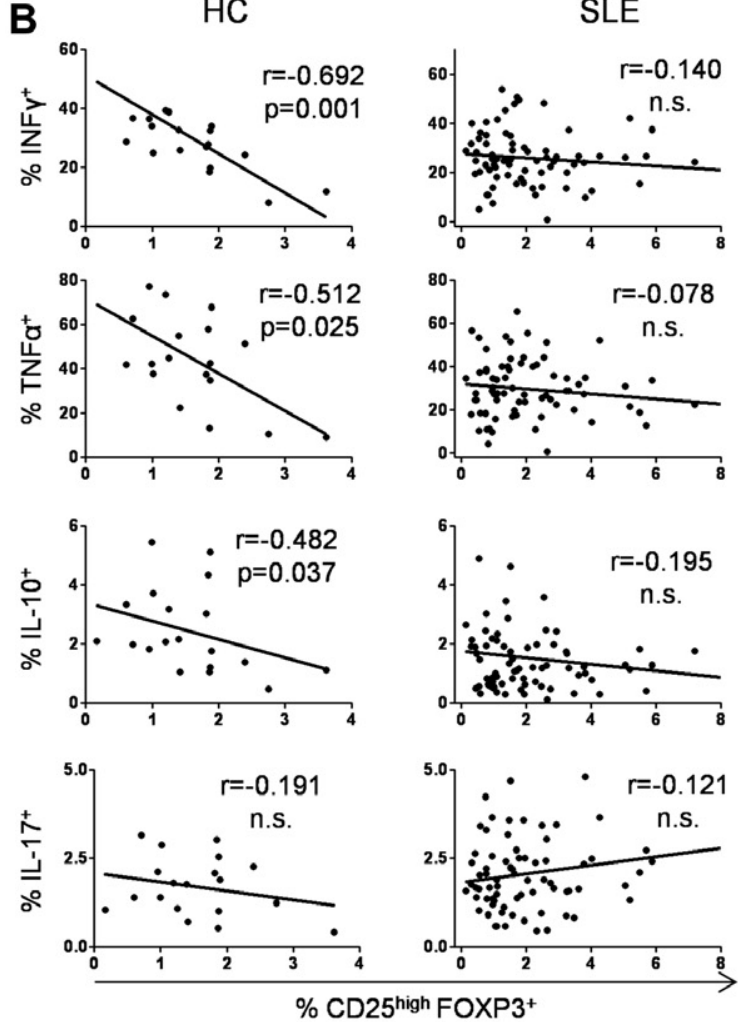
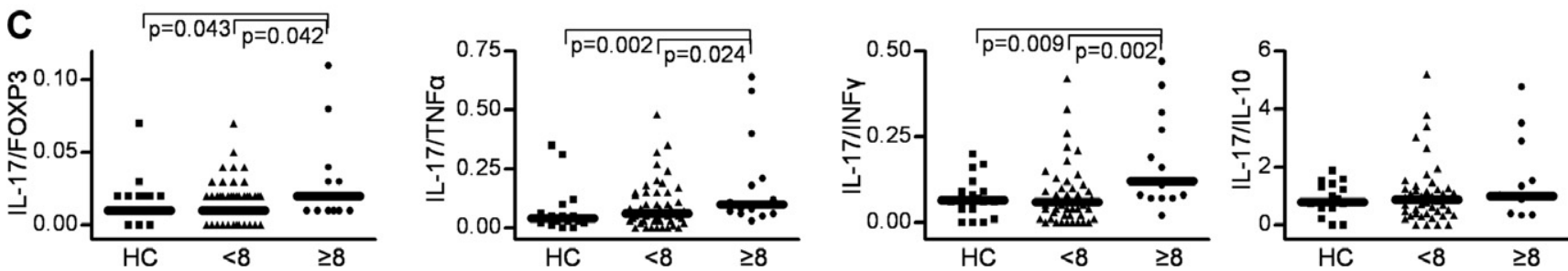

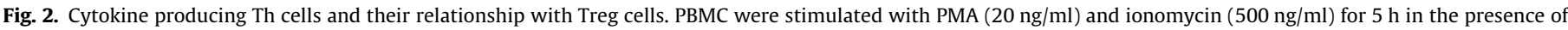

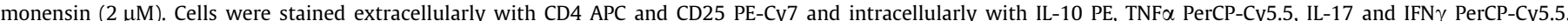

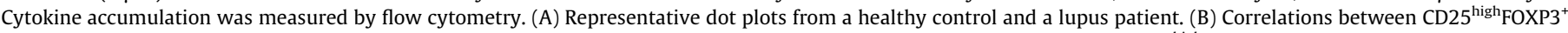

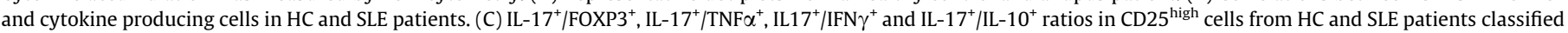
according to disease activity (SLEDAI score $\geqslant 8, n=16$ ). Lines represent median. HC: healthy controls; SLE: systemic lupus erythematosus patients.

of FOXP3 in CD25- cells could be an autoregulatory mechanism to induce $\mathrm{T}$ cell anergy, a FOXP3 associated feature in non-suppressive cells $[5,20]$. Our results also indicated that this enhancement was associated with the downregulation of $\mathrm{CD}^{+}$lymphocytes. The strong negative correlation detected between the size of $\mathrm{CD}^{+}$and $\mathrm{FOXP3}^{+}$populations $(r=-0.421, p<0.0001)$ suggests that the increased proportion of $\mathrm{CD}_{2} 5^{-} \mathrm{FOXP} 3^{+}$cells in SLE could be due to the higher resistance to apoptosis of these lymphocytes. Although increased apoptosis were widely observed in SLE $[21,22]$, they affect especially to naïve $\mathrm{CD} 4^{+} \mathrm{CD} 45 \mathrm{RA}^{+}$lymphocytes [22], thus explaining the negative correlation between the amounts of $\mathrm{CD}^{+}$and $\mathrm{CD} 25^{-} \mathrm{CD} 45 \mathrm{RO}^{+}$cells. Actually, most of the $\mathrm{CD} 25^{-} \mathrm{FOXP}^{+}$ cells from lupus patients are $\mathrm{CD}^{2} 5 \mathrm{RO}^{+}$, whereas this cell subset in healthy controls is mainly made up of $C^{2} 45 R A^{+}$cells $[8,19]$. Besides, the enhanced $\mathrm{CD}_{2} 5^{-} \mathrm{FOXP3}^{+}$population reported by other authors in SLE $[6-8,19]$, could be related to disease progression, since they did not include recent onset patients. However, our results are in disagreement with the study published by Zhang et al. [9], that shows increased numbers of $\mathrm{CD}^{-} 5^{-} \mathrm{FOXP3}^{+}$cells in untreated new onset lupus patients. This contradiction could be partially explained by patient selection, because some of our recently diagnosed lupus patients were under treatment, and it has been reported that $\mathrm{CD} 25^{-} \mathrm{FOXP3}^{+}$cells decreased in most active patients after treatment [9]. Furthermore, given that FOXP3 is also expressed by human activated $\mathrm{CD} 4^{+}$lymphocytes, the $\mathrm{CD} 25^{-} \mathrm{FOXP}^{+}$ population of untreated new onset active patients reported by Zhang et al., could include activated lymphocytes, since human CD25 expression is a continuum and it is very difficult to define or standardize $\mathrm{CD} 25^{-}, \mathrm{CD} 25^{\text {low }}$ and $\mathrm{CD} 25^{\text {high }}$ populations. In fact, our recent onset patient group showed the highest percentage of $\mathrm{CD}^{2} 5^{\text {low }} \mathrm{FOXP3}^{+}$cells.

On the other hand, the simultaneous analysis of $\mathrm{FOXP}^{+}$and cytokine producing Th cells allowed us to evaluate the relationship between these populations, using these associations as an indirect measure of the possible involvement of $\mathrm{FOXP}^{+}$subsets in controlling the function of effector T cells. Our results confirm the participation of conventional $\mathrm{CD} 25^{\text {high }} \mathrm{FOXP3} 3^{+}$Treg cells from healthy individuals in the regulation of $\mathrm{CD}^{+}$effector responses, mostly Th1 cells (IFN $\gamma$ and TNF $\alpha$ producing cells). There is emerging evidence supporting that defective Treg function to modulate cytokine production was related to the development or worsening of lupus. In spite of the normal amount of $\mathrm{CD} 25^{\text {high }} \mathrm{FOXP}^{+}$cells, our data suggest that Treg cells from lupus patients are dysfunctional, since the negative correlations between the number of Treg and 

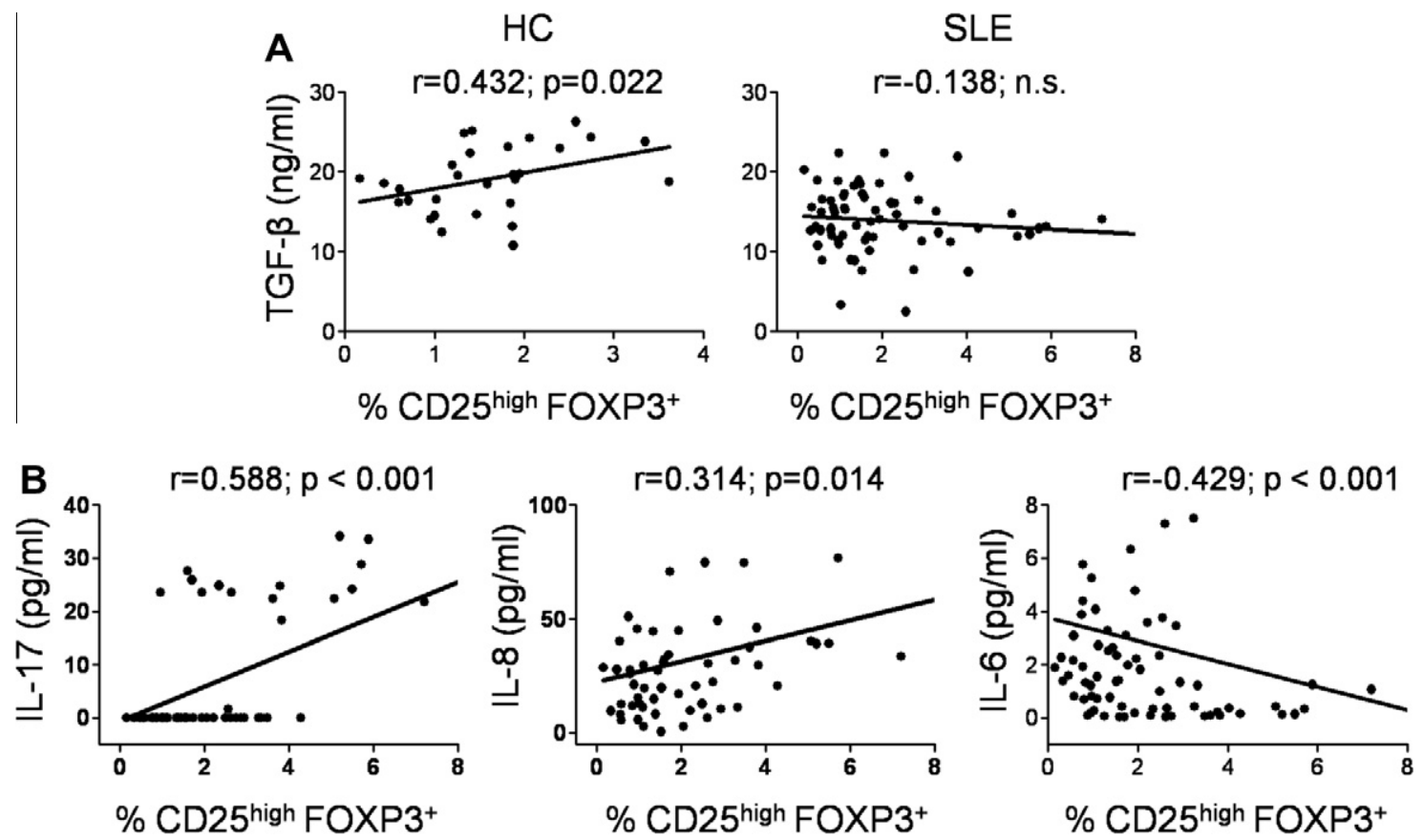

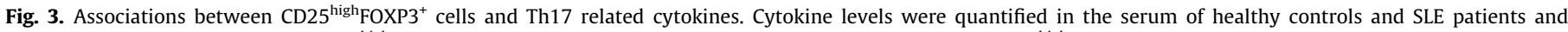

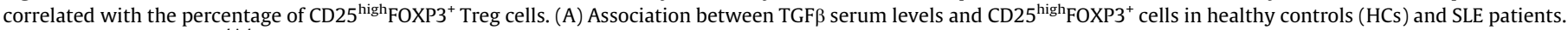
(B) The number of $\mathrm{CD} 25^{\text {high }} \mathrm{FOXP3}^{+}$cells from SLE patients correlated directly with IL-17 and IL- 8 and inversely with IL-6 levels.

IFN $\gamma$, TNF $\alpha$ or IL-10 secreting cells found in healthy subjects were disrupted in patients. Concerning the functional properties of Treg cells in SLE patients, contradictory results have been published. In fact, some authors showed defects on Treg function in SLE patients after in vitro evaluation of the ability to suppress effector cells or cytokine production $[2,23,24]$ whereas others have not found significant differences with healthy controls $[8,25]$. These controversial results could be due to the characteristics of patients, presenting different treatments and/or disease activity, or to the method used to evaluate the suppressive activity.

Conversely, the absence of negative correlations between $\mathrm{CD}^{-/ 5^{-/{ }^{\prime}}} \mathrm{FOXP3}^{+}$and cytokine producing cells in healthy individuals suggests that this population is not involved in the control of Th cell derived cytokines. Attempts to determine the functionality of $\mathrm{CD}^{2} 5^{-} \mathrm{FOXP3}^{+}$cells reached different conclusions $[19,26]$. Since separation of this population is not possible, determination of their possible functional activity is not currently available. Given that CD127 expression is downregulated after activation, we believe, in accordance with other authors $[19,26]$, that results obtained after isolating $\mathrm{CD} 25^{-} \mathrm{CD} 127^{-/ \text {low }}$ cells may not be extrapolated. In essence, our results clearly showed that low expression of CD127 could not be used as a surrogate marker for FOXP3 to isolate putative CD25-/low Treg cells, since the differences between percentages of $\mathrm{FOXP}^{+}$and $\mathrm{CD}^{2} 27^{-/ \mathrm{low}}$ in the bulk of $\mathrm{CD} 25^{-}$and $\mathrm{CD} 25^{\text {low }}$ populations were greatly discordant (Table 2 ).

Finally, this work provides interesting evidence supporting that CD25 $5^{\text {high }}$ cells in SLE are functionally altered. We showed that CD25 $5^{\text {high }}$ cells from patients with moderate/high disease activity tend to secrete more IL-17 and, importantly, present a decreased $\mathrm{FOXP3}^{+} / \mathrm{IL}^{-} 17^{+}$ratio as compared to healthy individuals. In addition, the balance in the production of cytokines is also dysregulated in this subset, since the IL- $17^{+} / \mathrm{IFN} \gamma^{+}$and IL- $17^{+} / \mathrm{TNF} \alpha^{+}$ratios were higher in active patients as compared to controls. Accordingly, IL17 and IFN $\gamma$ production by $\mathrm{CD}_{2} 5^{\text {high }} \mathrm{FOXP}^{+}$cells have been reported in both SLE patients and healthy controls [27]. All these data raise the possibility that $\mathrm{CD} 25^{\text {high }}$ cells in active SLE may display a tendency to be "Th17", accordingly with the skew towards a Th17 response reported in these patients [28-32]. Although the mechanism underlying Treg "trans-differentiation" into Th17 cells is yet to be determined, the deficiency of TGF $\beta$ and the increased levels of IL-6 found in patients, as well as the reduced Treg suppressive capacity, might explain it. In fact, IL-6, a Th17 inducer cytokine, has been shown to impair Treg activity $[33,34]$ and even convert Treg into cells able to produce IL-17 [35], whereas TGF $\beta$ is related to the development and maintenance of Treg cells. TGF $\beta$ levels seem to be critical to preserve Treg/Th17 balance, since high amounts promote Treg while low levels are necessary to Th17 differenciation [36]. If the conversion of Treg into Th17 cells actually occurs in lupus, it would explain the positive correlation found between the number of $\mathrm{CD} 25^{\text {high }} \mathrm{FOXP3}^{+}$cells and serum levels of IL17. So, although this relation may be surprising, it agrees with our previous findings and several reports showing a considerable plasticity between Th17 and Treg cells [10-12,34,35].

\section{Conclusions}

This work describes relevant phenotypic and functional features of $\mathrm{FOXP3}^{+}$cells from SLE patients. The upregulation of $\mathrm{CD} 25^{--}$ $\mathrm{FOXP}^{+}$population, which is related to disease progression and $\mathrm{CD}^{+}$drop, suggests a possible autoregulatory mechanism to induce anergy or a selective $T$ cell death of specific subsets. On the other hand, despite the normal frequency of $\mathrm{CD} 25^{\text {high }} \mathrm{FOXP}^{+}$cells found in SLE patients, its functionality could be impaired. Moreover, the increased proportion of IL- $17^{+}$cells among CD25 $5^{\text {high }}$ population and the positive correlation between IL-17 levels and Treg cells suggest that Treg cells from SLE patients could be prone to develop into Th17 cells, being CD25 $5^{\text {high }} \mathrm{IL}-17^{+}$cells an intermediate status of this "trans-differentiation".

\section{Acknowledgement}

The authors wish to thank ALAS (Asociación Lúpicos de Asturias) for its continuous encouragement. 


\section{References}

[1] Sakaguchi S, Sakaguchi N, Asano $M$, et al. Immunologic self-tolerance maintained by activated $\mathrm{T}$ cells expressing IL-2 receptor alpha-chains (CD25). Breakdown of a single mechanism of self-tolerance causes various autoimmune diseases. J Immunol 1995;155:1151-64.

[2] Gerli R, Nocentini G, Alunno A, et al. Identification of regulatory T cells in systemic lupus erythematosus. Autoimmun Rev 2009;8:426-30.

[3] Fontenot JD, Gavin MA, Rudensky AY. FOXP3 programs the development and function of $\mathrm{CD}^{+} \mathrm{CD}^{2} 5^{+}$regulatory T cells. Nat Immunol 2003;4:330-6.

[4] Buckner JH, Ziegler SF. Regulating the immune system: the induction of regulatory T cells in the periphery. Arthritis Res Ther 2004;6:215-22.

[5] Wang J, Ioan-Facsinay A, van der Voort EIH, et al. Transient expression of FOXP3 in human activated nonregulatory $\mathrm{CD}^{+} \mathrm{T}$ cells. Eur J Immunol 2007;37:129-38.

[6] Bonelli M, von Dalwigk K, Savitskaya A, et al. FOXP3 expression in $\mathrm{CD}^{+} \mathrm{T}$ cells of patients with systemic lupus erythematosus: a comparative phenotypic analysis. Ann Rheum Dis 2008;67:664-71.

[7] Lin S, Chen K, Lin C, et al. The quantitative analysis of peripheral blood FOXP3expressing $\mathrm{T}$ cells in systemic lupus erythematosus and rheumatoid arthritis patients. Eur J Clin Invest 2007;37:987-96.

[8] Suen J, Li H, Jong Y, et al. Altered homeostasis of $\mathrm{CD} 4\left(^{+}\right)$FoxP3 $\left(^{+}\right)$regulatory Tcell subpopulations in systemic lupus erythematosus. Immunology 2009;127:196-205.

[9] Zhang B, Zhang X, Tang FL, et al. Clinical significance of increased $\mathrm{CD}^{+} \mathrm{CD} 25^{-}$Foxp $^{+} \mathrm{T}$ cells in patients with new-onset systemic lupus erythematosus. Ann Rheum Dis 2008;67:1037-40.

[10] Koenen HJ, Smeets RL, Vink PM, et al. Human CD2 $5^{\text {high }}$ Foxp3 pos regulatory T cells differentiate into IL-17-producing cells. Blood 2008;112:2340-52.

[11] Beriou G, Costantino CM, Ashley CW, et al. IL-17-producing human peripheral regulatory T cells retain suppressive function. Blood 2009;113:4240-9.

[12] Valmori D, Raffin C, Raimbaud I, et al. Human ROR $\gamma \mathrm{t}^{+} \mathrm{TH} 17$ cells preferentially differentiate from naive FOXP3 ${ }^{+}$Treg in the presence of lineage-specific polarizing factors. P Natl Acad Sci USA 2010;107:19402-7.

[13] Annunziato F, Cosmi L, Liotta F, et al. The phenotype of human Th17 cells and their precursors, the cytokines that mediate their differentiation and the role of Th17 cells in inflammation. Int Immunol 2008;20:1361-8.

[14] Vanaudenaerde BM, Wuyts WA, Dupont LJ, et al. Interleukin-17 stimulates release of interleukin- 8 by human airway smooth muscle cells in vitro: a potential role for interleukin-17 and airway smooth muscle cells in bronchiolitis obliterans syndrome. J Heart Lung Transpl 2003;22:1280-3.

[15] El-Behi M, Ciric B, Dai H, et al. The encephalitogenicity of $T(H) 17$ cells is dependent on IL-1- and IL-23-induced production of the cytokine GM-CSF. Nat Immunol 2011;12:568-75.

[16] Zhang L, Yi H, Xia XP, et al. Transforming growth factor-beta: an important role in $\mathrm{CD} 4^{+} \mathrm{CD} 25^{+}$regulatory $\mathrm{T}$ cell and immune tolerance. Autoimmunity 2006;39:269-76.

[17] López P, Mozo L, Gutiérrez C, et al. Epidemiology of systemic lupus erythematosus in a northern Spanish population: gender and age influence on immunological features. Lupus 2003;12:860-5.

[18] Gómez J, Suárez A, López P, et al. Systemic lupus erythematosus in Asturias, Spain: clinical and serologic features. Medicine (Baltimore) 2006;85:157-68.
[19] Bonelli M, Savitskaya A, Steiner C, et al. Phenotypic and functional analysis of $\mathrm{CD}^{+} \mathrm{CD} 25^{-}$Foxp $^{+} \mathrm{T}$ cells in patients with systemic lupus erythematosus. J Immunol 2009;182:1689-95.

[20] Prado C, Gómez J, López P, et al. Dexamethasone upregulates FOXP3 expression without increasing regulatory activity. Immunobiology 2011;216:386-92.

[21] Wang H, Xu J, Ji X, et al. The abnormal apoptosis of T cell subsets and possible involvement of IL-10 in systemic lupus erythematosus. Cell Immunol 2005;235:117-21.

[22] Habib HM, Taher TE, Isenberg DA, et al. Enhanced propensity of T lymphocytes in patients with systemic lupus erythematosus to apoptosis in the presence of tumour necrosis factor alpha. Scand J Rheumatol 2009;38:112-20.

[23] Valencia X, Yarboro C, Illei G, et al. Deficient CD4 $4^{+} D 25^{\text {high }} \mathrm{T}$ regulatory cell function in patients with active systemic lupus erythematosus. J Immunol 2007; 178:2579-88.

[24] Gómez J, Prado C, López P, et al. Conserved anti-proliferative effect and poor inhibition of TNF alpha secretion by regulatory $\mathrm{CD} 4^{+} \mathrm{CD} 25^{+} \mathrm{T}$ cells in patients with systemic lupus erythematosus. Clin Immunol 2009;132:385-92.

[25] Miyara M, Amoura Z, Parizot C, et al. Global natural regulatory T cell depletion in active systemic lupus erythematosus. J Immunol 2005;175:8392-400.

[26] Yang H, Zhang W, Zhao L, et al. Are CD4 $4^{+} \mathrm{CD} 25^{-}$Foxp $3^{+}$cells in untreated newonset lupus patients regulatory T cells? Arthritis Res Ther 2009;11:R153.

[27] Dolff S, Bijl M, Huitema MG, et al. Disturbed Th1, Th2, Th17 and T(reg) balance in patients with systemic lupus erythematosus. Clin Immunol 2011;141:197-204.

[28] Chen XQ Yu Y, Deng HH, et al. Plasma IL-17A is increased in new-onset SLE patients and associated with disease activity. J Clin Immunol 2010;30:221-5.

[29] Shah K, Lee W, Lee S, et al. Dysregulated balance of Th17 and Th1 cells in systemic lupus erythematosus. Arthritis Res Ther 2010;12:R53.

[30] Prado C, de Paz B, Gómez J, et al. Glucocorticoids enhance Th17/Th1 imbalance and signal transducer and activator of transcription three expression in systemic lupus erythematosus patients. Rheumatology (Oxford) 2011;50:1794-801.

[31] Yang J, Chu Y, Yang X, et al. Th17 and natural Treg cell population dynamics in systemic lupus erythematosus. Arthritis Rheum 2009;60:1472-83.

[32] Xing Q, Wang B, Su H, et al. Elevated Th17 cells are accompanied by FoxP3 Treg cells decrease in patients with lupus nephritis. Rheumatol Int 2012;32:949-58.

[33] Dominitzki S, Fantini MC, Neufert C, et al. Cutting edge: trans-signaling via the soluble IL-6R abrogates the induction of FoxP3 in naive CD4 ${ }^{+} \mathrm{CD} 25 \mathrm{~T}$ cells. J Immunol 2007;179:2041-5.

[34] Zheng SG, Wang J, Horwitz DA. Cutting edge: Foxp $3^{+} \mathrm{CD} 4^{+} \mathrm{CD} 25^{+}$regulatory $\mathrm{T}$ cells induced by IL-2 and TGF-beta are resistant to Th17 conversion by IL-6. J Immunol 2008;180:7112-6.

[35] Xu L, Kitani I, Fuss W, et al. Cutting edge: regulatory $\mathrm{T}$ cells induce $\mathrm{CD}^{+} \mathrm{CD} 25^{-}$Foxp $^{-} \mathrm{T}$ cells or are self-induced to become Th17 cells in the absence of exogenous TGF- $\beta$. J Immunol 2007;178:6725-9.

[36] Bettelli E, Carrier Y, Gao W, et al. Reciprocal developmental pathways for the generation of pathogenic effector TH17 and regulatory T cells. Nature 2006;441:235-8. 